\title{
Chapter 3 \\ The EU-Turkey Customs Union: A Model for Future Euro-Med Integration
}

\author{
Subidey Togan
}

\subsection{Introduction}

After pursuing inward-oriented development strategies for 50 years, Turkey switched to outward-oriented policies in 1980. The policy of further opening up the economy was pursued through close association with the EU. Turkey applied for association with the EU (then the EEC) as early as 1959. The application ultimately resulted in the signing of the AA, commonly known as the Ankara Agreement, in 1963. The Additional Protocol to the AA was signed in 1970 and became effective in 1973. The basic aim of this protocol was the establishment of a CU. In 1995, it was agreed at the Association Council meeting that the CU between the EU and Turkey would go into effect on January 1, 1996.

This chapter analyzes the EU-Turkey CU and is structured as follows. After discussing issues related to trade in industrial goods in Sect. 3.2, Sect. 3.3 discusses TBT, Sect. 3.4 - competition policy, and Sect. 3.5 - IPR. Section 3.6 reports estimates of the administrative costs incurred by Turkey in adopting and implementing the CU. Section 3.7 discusses trade performance, FDI and problems faced by Turkey during the implementation of the CU. Section 3.8 offers conclusions.

\subsection{Customs Union}

A CU is usually defined as a form of trade agreement under which certain countries preferentially grant tariff-free market access to each other's imports and agree to apply a common set of external tariffs to imports from the rest of the world. In a CU,

\footnotetext{
S. Togan $(\bowtie)$

Bilkent University, Ankara, Turkey

e-mail: togan@bilkent.edu.tr
} 
four sets of issues have to be settled between the parties: coverage of the $\mathrm{CU}$, determination of the CCT, collection of CCT revenue and allocation of CCT revenue. In the case of the EU-Turkey $\mathrm{CU}$, the parties agreed from the outset that the CU should be restricted to industrial goods, that Turkey should accept the external tariff of the EU, that the CCT revenue would be collected by each party at the initial port of entry, and that the CCT revenue would accrue as income to the party collecting that revenue.

The Turkey-EU CUD of 1995 required Turkey to eliminate all customs duties, quantitative restrictions, charges with an equivalent effect to customs duties, and all measures with an equivalent effect to quantitative restrictions in trade of industrial goods with the EU as of January 1, 1996. In addition, Turkey was required to adopt the CCT of the EU against third-country imports and adopt all of the preferential agreements the EU has concluded and will conclude with third countries. As a result of these requirements, all of the industrial goods except for products of the ECSC complying with EU norms can circulate freely between Turkey and the EU. For ECSC products, Turkey signed an FTA with the EU in 1996, and as a result ECSC products have received duty-free treatment between the parties since 1999. Finally, it is important to note that the $\mathrm{CU}$ does not deal with agriculture and services, but according to the CUD, processed agricultural products are subject to special tariff arrangements.

According to Togan (1997), prior to the formation of the CU in 1994, the economy wide NPR in trade with the EU amounted to $10.2 \%$ and in trade with third countries to $22.1 \%$. Among the 49 tradable goods industries of the 1990 Turkish input-output table, there were three industries that had an NPR higher than $50 \%$ in trade with the EU, and 33 industries had an NPR less than $20 \%$. In the case of trade with third countries, there were five industries which had an NPR higher than $50 \%$ and 28 industries had an NPR less than $20 \%$. With the formation of the CU, NPRs have decreased substantially in almost all of the sectors. The economywide NPR during 2001 in trade with the EU amounted to $1.3 \%$. There was one industry that had an NPR higher than $50 \%$, nine industries had positive NPR less than $50 \%$, and for 39 industries, the NPR was $0 \%$ in trade with the EU. On the other hand, in the case of trade with third countries, the average NPR has amounted to $6.9 \%$. There was one industry which had an NPR higher than $50 \%, 13$ industries had an NPR less than $50 \%$ but more than $10 \%$, and for three industries the NPR was $0 \%$ in trade with third countries.

While the average NPR decreased from $10.2 \%$ in 1994 to $1.3 \%$ in 2001 for the EU, the average NPR decreased from $22.1 \%$ to $1.3 \%$ for Israel and the CEE countries that the EU had an FTA with. For developing countries that are granted GSP treatment, the average NPR decreased from $22.1 \%$ in 1994 to $2.7 \%$ in 2001. Finally, for countries like the US, Japan and Canada, for which the EU applies the CCT, average NPR decreased from $22.1 \%$ in 1994 to $6.9 \%$ in 2001. Thus, regarding access to the Turkish market, as a result of the formation of the $\mathrm{CU}$, almost all countries in the world have benefited from reductions in NPR in Turkey.

Regarding the access of Turkish goods to the EU market, the EU had already abolished the nominal tariff rates on imports of industrial goods from Turkey on 
September 1, 1971. However, at that time, certain exceptions were made. The EU had retained the right to charge import duties on some oil products over a fixed quota and to implement a phased reduction of duties on imports of particular textile products. The trade of products within the province of the ECSC has been protected by the EU through the application of NTM especially anti-dumping measures.

The primary effect of a $\mathrm{CU}$ is the expansion of trade flows among member countries, often at the expense of trade with non-members. This expansion is usually decomposed into trade creation and trade diversion. When trade diversion dominates trade creation, the $\mathrm{CU}$ tends to be welfare reducing. In the case of Turkey, the CU has offered the opportunity to adopt a more liberal trade regime since the CCT is lower than the pre-CU tariff. Thus, there is less potential for switching suppliers. As a result, the potential for trade diversion has been reversed. While domestic producers face more competition from non-members, the effect has been offset by consumer gains resulting from lower prices and by tariff revenues collected on imports from non-members.

The CUD requirements also apply to customs reform. Prior to the formation of the CU, Turkey had quite a complicated import regime. The Turkish Customs Administration was a traditional paper-based customs organization and declarants had to go to customs offices to register declarations. Since almost all shipments had to be physically inspected, the process at customs was very intrusive and time consuming. It often led traders to pay substantial facilitation money to speed up the process or to gain favor with customs officials in charge of their inspections.

Since the formation of the CU, Turkey has applied customs rules similar in substance to those contained in the EU's Customs Code. With the new Customs Law, Turkish customs legislation has been adjusted to both international and EU standards. Currently, the Turkish Customs Administration is fully automated and $99 \%$ of customs processes are conducted through computers via the BILGE (SCHOLAR) system. As part of its trade facilitation work, it is now able to carry out its control processes without having to open every single cargo shipment while retaining effective monitoring of the flow of goods and duties payable.

\subsection{Technical Barriers to Trade}

There are essentially two ways to eliminate TBT: harmonization and mutual recognition. The harmonization approach has been pursued intensively within the EU. As emphasized by the European Commission (2000), for a new member country, the elimination of TBT in trade with the EU requires (i) harmonization of the country's technical legislation with that of the EU's, (ii) the establishment of quality infrastructure comparable to that of the EU, encompassing the operators and operation of standardization, testing, certification, inspection, accreditation and metrology, and (iii) the development of a market surveillance and import control system as in the EU. On the other hand, under mutual recognition, countries agree to recognize each other's standards and conformity assessment procedures. But this 
approach based on mutual trust by the parties requires as a minimum a relatively high degree of harmonization of standards and testing procedures.

The CUD required that Turkey incorporate the EU instruments relating to the removal of TBT into its internal legal order within 5 years, and the list of these instruments was to be laid down within a period of 1 year. Furthermore, effective cooperation was to be achieved in the fields of standardization, metrology and calibration, quality, accreditation, testing and certification. Thus, the CUD required that Turkey adopt the harmonization approach in order to eliminate TBT.

Since the formation of the CU, Turkey has, to a very large extent, harmonized its standards with European and international ones. It has also harmonized its technical legislation with that of the EU, in particular in the New Approach area. There are problems with the Old Approach area, as there is no formal agreement on the transposition of the acquis in Turkey as it has been evolving systematically. On the other hand, harmonization of technical legislation in the non-harmonized sphere has been incomplete for very long time, limiting the free movement of goods in this sphere. For the non-harmonized area, Turkey adopted a regulation on mutual recognition as foreseen by the EU, but it entered into force as recently as January $1,2013$.

The establishment of quality infrastructure was a lengthy and complex process in Turkey. Until the formation of the CU, the country had neither the infrastructure nor the required technical knowledge. Establishing public awareness of the problem, acquiring the necessary knowledge and establishing the infrastructure took quite some time. But as of 2013, a relatively well functioning quality certification system has been in place in Turkey, comprised of the Turkish Standards Institution (TSE), the Turkish Accreditation Body (TÜRKAK) and the National Metrology Institute (UME).

A major difficulty faced during this period was obtaining the right to assign notified bodies that would be recognized by the EU. Note that the notified bodies are independent testing houses, laboratories, or product certifiers authorized by the EU member states to perform the conformity assessment tasks specified in directives. Turkey has received the right to assign notified bodies that would be recognized by the EU only by virtue of the Association Council Decision No 1/2006 of 2006.

The development of a market surveillance and import control system, as in the $\mathrm{EU}$, became even more challenging than establishing quality infrastructure. Again, the reasons are various. A successful consumer product safety related market surveillance system requires independence, visibility, a uniform surveillance policy, a uniform enforcement policy, the integration of market surveillance and import controls, stronger regions, more acting power for inspectors, and sufficient technical infrastructure. In addition, there were problems with the implementation of the import control system. As a result, until recently, the Turkish market surveillance and import control system could not be developed as in the EU, and the continuation of these problems has adversely affected the elimination of TBT in trade with the EU. 


\subsection{Competition Policy}

In Turkey there was no specific competition legislation and thus no competition policy enforcement for a very long time. The CUD required Turkey to adopt the EU competition rules, including measures regarding public aid, within 2 years.

Turkey did so in December 1994 when it adopted the Law on the Protection of Competition and established the CA, which has administrative and financial autonomy. The CA aims to ensure the formation and development of markets for goods and services in a free and sound competitive environment, to observe the implementation of the Competition Law, and to fulfill the duties assigned to it by the Law. The CA has played an important role in moving the Turkish economy forward towards greater reliance on competition-based and consumer-welfare oriented market mechanisms. According to the European Commission's Turkey Progress Reports and the OECD (2005), Turkey has shown significant progress on the antitrust issue. The Authority has a clear track record on the implementation of the competition rules. Furthermore, it is the advisory institute for the actions of public enterprises granted by two circulars issued by the Prime Minister's office in 1998 and 2001. All ministries have to receive the opinion of the CA about draft laws, by-laws, regulations and communiqués regarding issues that fall under the scope of Competition Law.

Article 34 of CUD bars Turkey and the EU member states from providing state resources to aid undertakings or economic sectors where doing so distorts or threatens to distort competition between the EU and Turkey, and under Article 39 (2) of CUD, Turkey must adapt all of its existing aid schemes to EU standards and comply generally with the notification and guidelines procedures established by the EU to control aid provided by member states. Article 37 of the CUD stipulates that within 2 years of implementing the CU, Turkey must adopt the necessary EU rules for the implementation of the provisions relating to state aid. Despite these deadlines, the required rules have not been adopted until recently. It was only in October 2010 that the law on state aid and subsidies were adopted by Parliament. The law foresees the establishment of the State Aid Monitoring and Supervisory Council along with the State Aid General Directorate for ensuring the effective application and enforcement of state aid rules under the CUD. But unfortunately, as of the end of 2013, the EU State Aid rules could not be implemented as the implementing regulations had not yet been adopted.

\subsection{Intellectual Property Rights}

Article 31 and Annex 8 of the CUD stipulated that Turkey must ensure adequate protection and enforcement of IPR and implement the Uruguay Round Agreement on TRIPS by 1999. Furthermore Turkey had to adopt legislation by January 1, 1999 
to secure the patentability of pharmaceutical products and processes. In addition Turkey had to accede to various international conventions.

To satisfy the requirements of the CUD, Turkey has been making substantial efforts to align its legislation with the acquis since 1995. The TPI was established in 1994. It is the main administrative body responsible for granting patents and utility models, registering designs, and dealing with trademarks, circuit topographies and geographical indications. The Turkish Patent Law went into effect in 1995, and in 2003 the Legislation on the Establishment and the Functions of TPI was promulgated. By 2013, Turkey was party to the various conventions on IPR mentioned in the CUD.

IPR enforcement is a challenging task in any country as it requires specific skills. There is a need for special courts for the settlement of disputes and for efficient services of public prosecutors, judges, patent attorneys and police. Regarding special courts, it should be emphasized that specialist judges with experience in patent and other IPR matters are essential in order to deliver reliable and predictable decisions on questions of infringement and validity as well as on damages payable by infringers. Similar considerations also hold for public prosecutors and police. Patent attorneys must have profound knowledge of natural sciences and the ability to communicate new technical concepts or developments on paper. While they are expected to be knowledgeable in a specific legal area, they must also have a deep knowledge of domestic and international law as well as the national laws of other countries. The patent attorney's most important role is to be able to apply his/her specialized legal and scientific knowledge to a new technical solution. He or she must also be able to properly write a patent specification and patent claims to lay the foundation for a new industrial property right. The patent attorney is also expected to provide advice on know-how licenses, including drafting license agreements or providing advice on the rights of employed inventors and advising clients on technical developments.

In Turkey, IPR holders whose rights have been infringed upon may take action to protect themselves through civil and criminal procedures against the infringer. Civil procedures include actions for the cessation of infringement and prevention of possible infringement, as well as measures for the compensation of moral and material damages, including indemnities and the appropriation of unfair profits made by the infringer.

The judicial infrastructure in IPR enforcement is made up of courts, offices of the public prosecutor, and the MoJ. The MoJ is responsible for the establishment of IPR courts, ensuring the effective operation of these courts, and training judges, public prosecutors and other staff. Until recently, Turkey had 23 specialized IPR courts. In parts of Turkey where there are no specialized courts, ordinary ones, designated by the Supreme Board of Judges and Public Prosecutors, can rule on intellectual property rights cases, and a Court of Appeals has been established for these cases. Enforcement authorities include police, municipal police and gendarmerie. In cases of IPR violations, criminal proceedings start at the moment the complaint is registered. The police have already established an IPR office within its General Directorate. Anti-smuggling and organized crimes departments are based 
within the general financial crimes departments of the police and gendarmerie, and they are authorized to handle related cases.

Turkey must provide measures, procedures and remedies necessary to ensure that the enforcement of IPR is fair and equitable. But this is not an easy task. The establishment of the enforcement mechanism took quite some time. As of 2013, the task was not yet complete. Although a relatively large number of judges, lawyers, enforcement body staff, police force members and customs officers have been trained in IPR-related issues, the number of trained personnel is still insufficient and the training of the personnel needs to be strengthened.

\subsection{Administrative Costs of Implementing the Customs Union}

To estimate the budgetary costs of assuming the obligations of the $\mathrm{CU}$, we used the detailed budget figures of different public institutions. While most of the budget figures come from the MoF for the period 1994-2009, expenditure data for institutions such as TÜRKAK, CA, TPI and UME were obtained directly from each institution. The data was aggregated under the headings of personnel expenditures, current expenditures and investment expenditures. Since the figures were given in nominal terms, we used the GDP deflator (price index) to convert all figures to 2009 prices. Next we used the average TRY/EUR exchange rate of 2009 to obtain the figures in terms of 2009 EUR.

Some of the institutions such as the Under-Secretariat for Foreign Trade, the Under-Secretariat of Customs and the Turkish Standards Institute were operating before the start of the $\mathrm{CU}$, and they employed a large number of personnel. The $\mathrm{CU}$ put pressure on them to employ additional staff as well as to train the staff in issues related to relevant acquis. In addition, they had to increase investment expenditures. As a result, when considering the budgetary costs of assuming the obligations of the $\mathrm{CU}$ for these institutions, we concentrated on their total expenditures consisting of personnel expenditures, current expenditures and investment expenditures. Noting that during the 1990-2009 period, Turkish real GDP increased at an annual rate of $3.9 \%$, we assumed that the total real expenditures of these institutions would have increased at the same annual growth rate as that of real GDP if the CU had not been implemented. The excess of actual to predicted expenditures of these institutions for the period 1996-2009 was then considered to be the budgetary cost of assuming the obligations of the CU.

On the other hand, institutions such as TÜRKAK, CA, TPI and UME were established either around 1995 or thereafter as a result of the requirements of the CU. They had to increase their personnel and investment expenditures considerably in order to meet the demands for additional personnel, training, and building the required infrastructure. As a result, in the case of these institutions, we considered 
total expenditures consisting again of personnel and current and investment expenditures over a period of 5 years after their establishment.

In some cases (for example, IPR enforcement), institutions such as the Ministry of Interior or MoJ were also involved, but it was not possible to derive the costs related to fulfilling the requirements of the $\mathrm{CU}$ from their budget data. In those cases, we took the cost figures of the relevant institutions from the studies of the Secretariat General of EU Affairs (2001, 2003, 2007).

Finally, we added the funding received from the EU (EU contribution) to the sum of the above figures, since these funds were not included in the budget figures. The calculations reveal that the costs of assuming the obligations of the CU have amounted to EUR 1,065.1 mn, and the share of the EU contribution in the total cost came to $8.83 \%$.

\subsection{Trade Performance, FDI and Criticism of the CU}

\subsubsection{Trade Performance}

In 1995, Turkish exports to the EU15 amounted to USD11.1 bn (51.2\% of Turkey's exports), while imports from the EU15 amounted to USD16.9 bn (47.2\% of Turkey's imports). ${ }^{1}$ With the formation of the CU, the share of imports from the EU15 in total imports went up from $47.2 \%$ in 1995 to $53 \%$ in 1996, but then started to decrease, reaching $31 \%$ in 2008. Similarly, the share of exports to the EU15 in total exports went up from $51.2 \%$ in 1995 to $54 \%$ in 1999, but then started to decrease, reaching $39.2 \%$ in 2008. A comparison of the average growth rate of imports from the EU15 prior to the formation of the CU with those observed after its implementation reveals that it declined from $14.2 \%$ in 1991-1995 to $3.9 \%$ in 1996-2001, but thereafter it increased to $19.8 \%$ in 2002-2008. On the other hand, the effect of the CU on exports also seems to be of limited importance initially. Whereas the annual average growth rate of exports to the EU15 was $9.6 \%$ in 19911995 , it declined to $6.5 \%$ in $1996-2001$, but then increased to $18.6 \%$ in $2002-$ 2008.

While total exports declined by $22.6 \%$ in 2009 (during the great recession), the decline in exports to the EU15 amounted to $24 \%$. Similarly, while total imports declined by $30.2 \%$ in 2009, imports from the EU15 declined by $23.6 \%$. Both exports and imports recovered in 2010 and thereafter. While exports to the EU15 amounted to USD49.4 bn in 2012, forming $32.4 \%$ of total exports, imports from the EU15 amounted to USD73.1 bn, forming $30.9 \%$ of total imports.

The above considerations reveal that the formation of the CU between Turkey and the EU led to increases in exports to the EU only after an adjustment period of

\footnotetext{
${ }^{1}$ For reasons of analytical consistency we compared data for EU15 over the entire 1990-2012 period despite subsequent EU enlargements.
} 
almost 5 years. Similar considerations also hold for imports from the EU. The reasons may be various. First, the formation of the $\mathrm{CU}$ did not lead to substantial decreases in trade barriers on the EU side, as the EU had abolished the nominal tariff rates on imports of industrial goods from Turkey long before the formation of the CU (in 1971). With the formation of the CU, certain quotas applied by the EU were abolished but the EU retained the right to impose anti-dumping duties. Second, Turkey started to take measures in order to eliminate TBT only after 2003. Third, during the 1990s, economic crises began to affect the Turkish economy with increasing frequency. Periods of economic expansion have alternated with periods of equally rapid decline. Fourth, with substantial decreases in trade barriers on the Turkish side in 1996, an increase in imports was inevitable as long as it was not accompanied by a real devaluation of the Turkish Lira. But there was essentially no change in REER during 1996, and thereafter the REER appreciated until the currency crisis of 2001, when the REER depreciated considerably. Thereafter, the REER started to appreciate again, stimulating import growth and hampering the growth of exports and thus leading to substantial trade balance deficits. Finally, we note that the appreciation of the EUR against the USD led to increases in the USD value of EU exports which is reflected in higher USD trade values of Turkish imports from the EU.

\subsubsection{FDI}

Turkey was not successful in attracting FDI inflows for a very long time. From 1990 to 1995 , annual FDI inflows amounted to only USD745 $\mathrm{mn}$. This poor record was caused by economic and political uncertainties surrounding the country and the enormous institutional, legal and judicial obstacles faced by foreign investors in Turkey. Foreign-owned firms had been subject to special authorizations and sectoral limitations. According to the Foreign Investment Advisory Service (2001a, b), seven major problems impeded the operations of foreign enterprises until the early 2000s: (i) political instability, (ii) government hassle, (iii) a weak judicial system, (iv) heavy taxation, (v) corruption, (vi) deficient infrastructure and (vii) competition from the informal economy. During the period of 1996-2000, average annual FDI inflows amounted to USD846 mn. Thus, there was no substantial improvement after the formation of the CU. The FDI inflows started to increase only after 2001, and reached USD20.2 bn in 2006, USD22.1 bn in 2007 and USD19.8 bn in 2008. This considerable improvement seems to be the result of the EU's 2004 decision to begin membership negotiations with Turkey, the liberalization measures introduced after the 2001 crisis and the implementation of the privatization program after 2002 . During the period of great recession in 2009-2010, FDI inflows amounted on average to USD8.9 bn, increasing to USD16 bn in 2011 and then decreasing to USD13 bn in 2012. The EU has been the largest source of origin over the past 10 years, accounting for three-quarters of total FDI inflows. 
Although the investment climate in Turkey has improved considerably over the last 7 years, the change is still not reflected in various international competitiveness studies such as the Doing Business Survey (World Bank 2013), which ranked Turkey 69th out of 189 countries. On the other hand, according to the OECD (2006) study, Turkey's most restrictive sectors are air and maritime transport, followed by electricity, and its most liberal sectors are in manufacturing, together with some services subsectors such as telecommunications, insurance services and part of business services. Finally, according to the Services Trade Restrictiveness Database of the World Bank summarized by Borchert et al. (2012a, b), the most restrictive service sectors are professional services, transportation services and retail trade.

\subsubsection{Criticism of the Customs Union}

The EU-Turkey CU has not been without its critics. The policy stakeholders emphasize the following problems, as pointed out by Akman (2010). First, the EU's trade partners that have concluded an FTA with the EU or are in FTA negotiations with the EU refrain from concluding an FTA with Turkey despite the 'Turkey Clause' included in the FTA concluded by the EU. Second, there are asymmetric effects in trade agreements concluded by the EU and Turkey. In particular, Turkey cannot negotiate an FTA with third counties on similar terms like the EU did. Third, there are latecomer effects. In particular, Turkey can conclude an FTA only after the EU has concluded an FTA. As a result an FTA with Turkey is concluded usually after a couple of years after the conclusion of an FTA with the EU. This puts Turkish exporters at a disadvantage with regards to EU exporters, who can obtain preferential status by penetrating into third country markets several years earlier. Fourth, imports from third countries by way of trade deflection via the EU induce tariff revenue losses for Turkey, an issue that has not received sufficient attention in the customs modernization process. Fifth, the EU has its own priorities reflected in its FTA that are concluded, and these agreements do not take into account Turkey's special interests. Sixth, Turkey cannot enter into an FTA with third countries with which the EU has not accorded a deal. Finally, it has been emphasized that international road transport has been hampered by the bilateral quota system and visa restrictions imposed by certain EU member states.

\subsection{Conclusions}

The EU-Turkey CU of 1995 has been a major instrument of integration into the EU and global markets for Turkey, offering the country powerful tools to reform its economy. It has credibly locked Turkey into a liberal foreign trade regime for 
industrial goods and holds the promise of Turkey's participation in the EU internal market for industrial products. As a result, Turkish producers of industrial goods have become exposed to competition from imports and they operate within one of the largest FTAs for industrial products in the world. They are now protected by tariffs from external competition to exactly the same extent as EU producers are and as such, face competition from duty-free imports of industrial goods from worldclass pan-European firms. In return, Turkish industrial producers have duty-free market access to the European Economic Area (EU and EFTA).

Fulfilling the requirements of the $\mathrm{CU}$ has been quite challenging. Turkey has introduced major reforms. But it has faced difficulties, in particular when trying to eliminate the TBT in trade with the EU, adopting and implementing the EU's competition policy provisions on state aid and ensuring adequate and effective protection of IPR. In those cases, the process of fulfilling the requirements of the $\mathrm{CU}$ even after 17 years is not complete.

One lesson that can be derived from the Turkish experience is that trade liberalization achieved through a preferential trade agreement such as the EU-Turkey CU can successfully move the economy from a government-controlled regime to a market-based one. Another issue is related to the existence of political will on the side of policymakers to reform the economy. In Turkey there was political will to achieve the goal of EU economic integration on the path to becoming a full member of the EU. As a result, in addition to opening up its markets to industrial goods imports from the EU, accepting the EC's CCT, and adopting all of the preferential agreements the EU has concluded with third countries, Turkey has also accepted the EU's customs provisions, its harmonization approach to the elimination of TBT, its competition policy, its IPR acquis and its commercial policy regulations. Although the administrative costs of implementing the requirements of the $\mathrm{CU}$ have been quite substantial, Turkey has incurred these costs in the hopes of becoming a full member of the EU. Moreover, there was almost no resistance to the integration process on the part of Turkish public.

Other countries may not have the prospect of EU membership as an incentive, but those countries may still be interested in integrating with the EU in order to achieve relatively high but sustainable economic growth, as measured by growth in real per capita income. In such a situation, the country could try to sign a FTA with the EU, but adopt, as emphasized by Messerlin et al. (2011), only those policies of the EU that are considered pro-growth.

Acknowledgement The author is grateful to Luc De Wulf and Jean-Pierre Chauffour for excellent comments. The author would like to thank Dr. Ahmet Kesik and Ali Mercan Aydın of the MoF of Turkey for providing detailed budget data, and to Ertan Tok for excellent research assistance. 


\section{References}

Akman S (2010) The European union's trade strategy and its reflection on Turkey: an evaluation from the perspective of free trade agreements. Paper presented at the IKV workshop on the interface between the world trading system and global issues: challenges for the WTO, Turkey and the European Union, Istanbul, 14-15 May

Borchert I, Gootiiz B, Mattoo A (2012a) Guide to the services trade restrictions database, vol 6108, World Bank policy research working paper. The World Bank, Washington, DC

Borchert I, Gootiiz B, Mattoo A (2012b) Policy barriers to international trade in services: evidence from a new database, vol 6109, World Bank policy research working paper. The World Bank, Washington, DC

European Commission (2000) Guide to the implementation of directives based on the new approach and the global approach. Office of Official Publications of the European Communities, Luxembourg

Foreign Investment Advisory Service (2001a) Turkey: a diagnostic study of the foreign direct investment environment. World Bank and the Treasury of Turkey, Ankara

Foreign Investment Advisory Service (2001b) Turkey: administrative barriers to investment. World Bank and the Treasury of Turkey, Ankara

Messerlin P, Emerson M, Jandieri G, Le Vernoy A (2011) An appraisal of the EU's trade policy towards its eastern neighbours: the case of Georgia. Sciences Po, Paris and Centre for European Policy Studies, Brussels

OECD (2005) Competition law and policy in Turkey. Organization for Economic Cooperation and Development, Paris

OECD (2006) OECD's FDI regulatory restrictiveness index: revision and extension to more economies, vol 4/2006, Working paper on international investment. Organization for Economic Cooperation and Development, Paris

Secretariat General for EU Affairs (2001) National programme of Turkey for the adoption of the EU acquis. http://www.abgs.gov.tr/index.php?p=196\&l=2. Accessed 17 July 2014

Secretariat General for EU Affairs (2003) National programme of Turkey for the adoption of the EU acquis. http://www.abgs.gov.tr/index.php?p=196\&l=2. Accessed 17 July 2014

Secretariat General for EU Affairs (2007) Turkey's programme for the alignment with the acquis 2007-2013. http://www.abgs.gov.tr/index.php?p=196\&l=2. Accessed 17 July 2014

Togan S (1997) Opening up the Turkish economy in the context of the CU with EU. J Econ Integr 12:157-179

World Bank (2013) Doing business 2014. The World Bank, Washington, DC 